ISSN : 2615-1995, E-ISSN : 2615-0654

J. Madani., Vol. 4, No. 2, September 2021 (109 - 125)

(C)2018 Lembaga Kajian Demokrasi

https://doi.org/10.33753/madani.v4i2.158

\title{
Pengaruh Profitabilitas, Likuiditas, Leverage, dan Intensitas Aset Tetap Terhadap Agresivitas Pajak
}

\author{
Lilis Karlina \\ Fakultas Ekonomi dan Bisnis, Universitas Pamulang \\ lisna13lilis@gmail.com
}

\begin{abstract}
Abstrak
Penelitian ini bertujuan untuk membuktikan secara empiris pengaruh profitabilitas, likuiditas, leverage dan intensitas aset tetap terhadap agresivitas pajak (Studi empiris pada perusahaan pertambangan yang terdaftar di Bursa Efek Indonesia periode 2012-2016). Populasi yang digunakan dalam penelitian ini sebanyak 46 perusahaan pertambangan yang terdaftar di Bursa Efek Indonesia periode 2012-2016. Metode penelitian yang digunakan yaitu kuantitatif, yakni melalui metode purposive sampling dengan sampel 12 perusahaan terdaftar di Bursa Efek Indonesia periode 20122016. Model dalam penelitian ini yaitu regresi panel dengan menggunakan aplikasi Eviews 8. Teknik analisis data yang digunakan dalam penelitian ini menggunakan analisis linear berganda. Hasilnya menunjukkan bahwa faktor profitabilitas, likuiditas dan intensitas asset tetap berpengaruh tidak signifikan terhadap agresivitas pajak. Sedangkan faktor leveragemempengaruhi secara signifikan terhadap agresivitas pajak. Dengan demikian, profitabilitas, likuiditas, leverage dan intensitas asset tetap secara bersama-sama berpengaruh signifikan terhadap agresivitas pajak.
\end{abstract}

Kata Kunci : Profitabilitas, Likuiditas, Leverage, Intensitas, Agresivitas Pajak.

\begin{abstract}
This study aims to empirically prove the effect of profitability, liquidity, leverage and intensity of fixed assets on tax aggressiveness (Empirical study on mining companies listed on the Indonesia Stock Exchange for the period 20122016). In this study there were a population of 46 mining companies listed on the Indonesia Stock Exchange for the period 2012-2016. The research method used in this study was quantitative. Through purposive sampling method, researchers obtained a sample of 12 companies listed on the Indonesia Stock Exchange for the period 2012-2016. The model in this study is panel regression using the Eviews 8 application. The data analysis technique in this study uses multiple linear analysis. The results of this study indicate that the profitability, liquidity and intensity of fixed assets have no significant effect on tax aggressiveness, while the leverage factor has a significant effect on tax aggressiveness. Profitability, liquidity, leverage and intensity of fixed assets together have a significant effect on tax aggressiveness.
\end{abstract}

Keywords : Profitability, Liquidity, Leverage, Intensity, Tax Aggressiveness.

\section{PENDAHULUAN}

Indonesia adalah Negara berkembang yang memiliki jumlah penduduk cukup besar. Indonesia menjadi Negara kepulauan terbesar dan memiliki potensi kekayaan alam yang sangat berlimpah, dimana letak geografis Indonesia juga cukup strategis. Indonesia merupakan salah satu kawasan lalu lintas perdagangan dunia, selain 
itu Indonesia juga membuka sisi bagi banyak perusahaan dari dalam maupun luar negeri yang telah beroperasi di Indonesia. Hal ini juga dapat menguntungkan Indonesia untuk menambah penerimaan dari sektor pajak.

Penerimaan Negara diperoleh dari sektor pajak, yaitu berasal dari penerimaan pajak penghasilan, pajak pertambahan nilai dan pajak penjualan atas barang mewah. Selain itu penerimaan diperoleh juga yang berasal dari bea masuk, cukai, pajak bumi dan bangunan, bea meterai, bea perolehan hak atas tanah dan bangunan, dan penerimaan lainnya yang diatur dengan peraturan perundang undangan di bidang perpajakan. Serta, penerimaan Negara yang berasal dari minyak dan gas bumi yang di dalamnya terkandung unsur pajak dan royalti, diperlakukan sebagai penerimaan perpajakan.

Pajak diakui sebagai beban yang harus dibayar bagi para wajib pajak. Wajib pajak pribadi maupun badan dikenakan pajak atas penghasilan yang diterima. Adanya pungutan pajak secara otomatis akan mengurangi total pendapatan atau laba bersih yang diterima oleh wajib pajak. Hal tersebut menyebabkan perusahaan selalu mencari cara untuk menghindari beban pajaknya. Rego menyatakan, penghindaran pajak dilakukan untuk mengefisienkan pajak secara legal (Rego, 2003). Perusahaan akan lebih agresif apabila menerima beban pajak yang besar (Chen et al., 2010). Menurut Frank, tindakan agresivitas pajak dapat dilakukan baik secara legal (tax avoidance) maupun secara illegal (tax evation) (Mary Margaret Frank, Luann J Lynch, 2009).

Seperti halnya pemilik perusahaan pada umumnya, bahwa setiap perusahaan menginginkan hasil laba yang tinggi dan kinerja yang baik dari para manajemen perusahaan. Demikian pula manajemen perusahaan, mereka juga menginginkan kompensasi yang seimbang dari hasil kinerja mereka. Beberapa manajer bahkan melakukan manajemen laba untuk meningkatkan laba untuk kepentingan pribadi dari pihak internal dengan memanfaatkan kebijakan akuntansi (Scott, 2009).

Agresivitas pajak perusahaan merupakan keinginan perusahaan untuk meminimalkan beban pajak yang dibayar dengan cara yang legal, illegal, maupun kedua-duanya (Novia Bani Nugraha, 2015). Agresivitas pajak perusahaan juga dinilai dari seberapa besar perusahaan tersebut mengambil langkah penghindaran pajak dengan memanfaatkan celah-celah yang ada dalam peraturan perpajakan. Dengan demikian, perusahaan akan dianggap semakin agresif terhadap perpajakan.

Kasus pajak agresif perusahaan di Indonesia sering terjadi, salah satunya yaitu kasus Sinar Mas Group. Kasus ini dimulai dari laporan masyarakat dan diperkuat temuan BPK (Badan Pemeriksa Keuangan) pada Januari 2014. Dimana disinyalir PT. Sinar Mas Group telah melakukan penyelewengan pajak dana reboisasi melalui tiga anak perusahaannya atas lahan seluas 2.000 hektar sehingga merugikan Negara sebesar Rp. 181,7 miliar. Tiga anak perusahaan yang diduga melakukan pengemplangan pajak tersebut adalah PT. Wirakarya Sakti, PT. Rimba Hutani Mas dan PT. Tebo Multi Agro. Ketiga perusahaan milik Sinar Mas tersebut merupakan perusahaan Hutan Tanaman Industri (HTI) yang beroperasi di lima kabupaten di Jambi yaitu Kabupaten Tanjung Jabung Barat, Tanjung Jabung Timur, Batang Hari, Muaro Jambi dan Tebo (Suprapto, 2019).

Kasus penghindaran pajak yang ditemukan di Sumatera Utara saat pihaknya bertugas di Kanwil Pajak Sumut II Pematangsiantar. Dirjen Pajak menemukan tujuh kecurangan yang dilakukan para pengembang property dalam melakukan penghindaran pajak. Pertama, Penggunaan harga di bawah harga jual sebenarnya dalam menghitung dasar pengenaan pajak (DPP). Kedua, tidak mendaftarkan diri menjadi Pengusaha Kena Pajak (PKP) tetapi menagih Pajak Pertambahan Nilai (PPN). Ketiga, tidak melaporkan seluruh penjualan. Keempat, tidak memotong dan memungut Pajak Penghasilan $(\mathrm{PPh})$. Kelima, mengkreditkan pajak masukan secara tidak sah. Keenam, penghindaran PPn Barang Mewah dan PPh pasal 22 atas hunian mewah. Ketujuh, menjual tanah dan bangunan, tetapi yang dilaporkan hanya penjualan tanah.

Menurut Rodriguez dan Arias (Suyanto \& Supramono, 2012), profitabilitas adalah faktor 
penentu beban pajak, karena perusahaan dengan laba yang lebih besar akan membayar pajak yang lebih besar pula. Sebaliknya, perusahaan dengan tingkat laba yang rendah maka akan membayar pajak yang lebih rendah atau bahkan tidak perlu membayar pajak jika mengalami kerugian. Profitabilitas yang rendah dapat mencerminkan perusahaan mengalami kesulitan untuk memenuhi kewajiban jangka pendek.

Hasil penelitian yang dilakukan oleh Nugraha dan Meiranto menyatakan bahwa profitabilitas berpengaruh positif tidak signifikan terhadap Agresivitas Pajak (Novia Bani Nugraha, 2015). Namun, hasil penelitian yang dilakukan oleh Prakosa (Prakoso, 2014) menyatakan bahwa profitabilitas berpengaruh negatif signifikan terhadap agresivitas pajak dan Ardyansyah dan Zulaikha (Ardyansah, 2014) menemukan bahwa profitabilitas tidak berpengaruh signifikan terhadap Effective Tax Rate (ETR).

Pajak merupakan salah satu bagian dari kewajiban jangka pendek perusahaan. Kemampuan perusahaan untuk melaksanakan kewajiban jangka pendek dapat dilihat dari rasio likuiditas. Apabila perusahaan memiliki rasio likuiditas yang tinggi maka perusahaan tersebut sedang berada dalam kondisi arus kas yang lancar. Kewajiban jangka pendek akan mampu dipenuhi apabila rasio likuiditas perusahaan sedang dalam keadaan yang tinggi (Suyanto \& Supramono, 2012). Apabila perusahaan sedang berada dalam kondisi keuangan yang baik, pemerintah berharap agar perusahaan tersebut melunasi atau melaksanakan kewajiban pajaknya tepat waktu.

Kesulitan likuiditas dapat memicu perusahaan untuk tidak taat terhadap peraturan pajak sehingga dapat mengarah pada tindakan agresif terhadap pajak perusahaan (Putri, 2014). Sejalan dengan penelitian Ida Bagus Putu Fajar Adisamartha dan Naniek Noviari yang menyatakan Faktor likuiditas dan intensitas persediaan berpengaruh positif dan signifikan pada tingkat agresivitas pajak, sementara faktor leverage dan intensitas asset tetap tidak berpengaruh signifikan pada tingkat agresivitas wajib pajak badan (Ida Bagus Putu Fajar Adisamartha, 2015).

Leverage adalah rasio yang menandakan besarnya modal eksternal yang digunakan perusahaan untuk melakukan aktivitas operasionalnya. Hasil dari perhitungan rasio leverage menandakan seberapa besar aset yang dimiliki perusahaan berasal dari modal pinjaman perusahaan tersebut. Apabila perusahaan memiliki sumber dana pinjaman tinggi, maka perusahaan akan membayar beban bunga yang tinggi pula kepada kreditur. Beban bunga akan mengurangi laba, sehingga dengan berkurangnya laba maka mengurangi beban pajak dalam satu periode berjalan. Perusahaan dapat menggunakan tingkat leverage untuk mengurangi laba dan akan berpengaruh terhadap berkurangnya beban pajak (Houston, 2001).

Teori akuntansi positif dengan debt covenant menyatakan; semakin tinggi hubungan perusahaan dengan pihak ketiga (kreditur) maka perusahaan akan lebih menjaga laba periode berjalan dengan tujuan menjaga stabilitas kinerja perusahaan yang dijelaskan melalui laba karena semakin tingginya kepentingan perusahaan dengan kreditur maka kreditur akan lebih mengawasi perusahaan dengan alasan kelangsungan pinjaman modal eksternal. Sehingga perusahaan dengan tingkat Leverage yang tinggi tidak akan agresif dalam hal perpajakannya karena diharapkan mampu menjaga stabilitas laba periode berjalan, salah satunya dengan mengalokasikan laba periode mendatang ke laba periode berjalan.

Hasil penelitian yang dilakukan oleh Nugraha dan Meiranto membuktikan bahwa leverage berpengaruh negatif signifikan terhadap agresivitas pajak (Novia Bani Nugraha, 2015). Namun hasil penelitian berbeda yang diperoleh Putri yang menyatakan bahwa leverage berpengaruh positif signifikan terhadap Tarif Pajak Efektif (Putri, 2014).

Intensitas aset tetap merupakan rasio yang menandakan intensitas kepemilikan aset tetap suatu perusahaan dibandingkan dengan total aset. Kepemilikan aset tetap yang tinggi akan menghasilkan beban depresiasi atas aset yang besar pula, sehingga laba perusahaan akan berkurang akibat adanya jumlah aset tetap yang besar. Tingginya jumlah aset yang ada di perusahaan akan meningkatkan agresivitas pajak 
perusahaan. Intensitas kepemilikan aset tetap dapat mempengaruhi beban pajak perusahaan karena adanya beban depresiasi yang melekat pada aset tetap.

Penelitian ini bermaksud dapat mengintegrasikan penelitian yang telah ada sebelumnya mengenai pengaruh yang ditimbulkan oleh profitabilitas, likuiditas, leverage, dan intensitas asset tetap terhadap agresivitas pajak. Penelitian ini dilakukan untuk mancari informasi terkait dengan ketaatan perusahaan dalam membayar pajak atau perusahaan melakukan tindakan agresivitas pajak. Menurut Kementerian Keuangan RI pemerintah Indonesia telah mengeluarkan berbagai kebijakan perpajakan, antara lain: (i) penurunan tarif $\mathrm{PPh}$ badan dari $28 \%$ menjadi 25\% (UU No.36 Tahun 2009), (ii) keringanan $\mathrm{PPh}$ sebesar $5 \%$ bagi perusahaan yang minimal $40 \%$ saham dimiliki publik dan (iii) pemberian insentif berupa pajak ditanggung pemerintah (DJP) atas PPh, PPN dan bea masuk guna mendorong investasi dan kegiatan usaha dalam negeri (Novia Bani Nugraha, 2015).

Dengan adanya kebijakan tersebut diharapkan perusahaan akan membayar pajak sesuai dengan ketentuan yang berlaku karena kebijakan yang baru telah menurunkan tarif pajak bagi perusahaan yang tentunya juga menguntungkan bagi perusahaan. Namun pada kenyataannya masih saja terjadi kecurangan yang dilakukan perusahaan dalam hal usaha menurunkan beban pajak yang harus dibayarkan (Novia Bani Nugraha, 2015). Penelitian ini menggunakan proksi effective tax rate (ETR) sebagai pengukuran agresivitas pajak, ETR di anggap mampu merefleksikan perbedaan antara perhitungan laba buku dengan laba fiskal (Putri, 2014).

\section{METODE}

Penelitian ini merupakan penelitian kuantitatif. Menurut Sugiyono, penelitian kuantitatif dalam melihat hubungan variabel terhadap obyek yang diteliti lebih bersifat sebab dan akibat (kausal), sehingga dalam penelitiannya ada variabel dependen maupun independen (Sugiyono, 2019). Penelitian ini bertujuan untuk menganalisa dan menjelaskan pengaruh variabel independen, yaitu profitabilitas, likuiditas, leverage, serta intensitas asset tetap terhadap variabel dependen, yaitu agresivitas pajak. Penelitian ini menggunakan perusahaan pertambangan yang terdaftar di Bursa Efek Indonesia (BEI) pada tahun 2012-2016.

Kemudian menurut Sugiyono, populasi merupakan wilayah generalisasi yang terdiri atas obyek atau subyek yang mempunyai kualitas dan karakteristik tertentu yang ditetapkan oleh penelitian untuk dipelajari serta ditarik kesimpulan (Sugiyono, 2019). Populasi dalam penelitian ini sebanyak 46 perusahaan pertambangan yang ada di Bursa Efek Indonesia periode 2012-2016.

Selanjutnya teknik pengambilan sampel dalam penelitian ini menggunakan metode purposive sampling dengan kriteria sebagai berikut:

1. Menyediakan laporan tahunan 2012-2016 serta tidak didelisting selama periode pengumpulan data.

2. Perusahaan tidak mengalami rugi fiskal supaya tidak menyebabkan distorsi dalam pengukuran penghindaran pajak.

3. Mempublikasikan laporan keuangan dalam mata uang rupiah.

Dengan melihat kriteria-kriteria dari metode purposive sampling maka sampel dalam penelitian ini sebanyak 12 perusahaan pertambangan yang terdaftar di Bursa Efefk Indonesia periode 20122016.

Adapun subyek penelitian ini adalah perusahaan pertambangan. Data-data yang digunakan meliputi laporan keuangan periode 2012-2016, gambaran umum perusahaan dan data lain yang dibutuhkan dalam penelitian. Variabel independen terdiri dari profitabiltas, likuiditas, leverage, dan intensitas asset tetap. Variabel dependen, yaitu agresivitas pajak. Definisi operasional variabel-variabel dalam penelitian ini sebagai berikut:

\section{Variabel Independen \\ Profitabilitas}

Profitabilitas yang dimaksud adalah kemampuan perusahaan untuk memperoleh keuntungan. Menurut Sudarmadji dan Sularto (2007), profitabilitas merupakan indikator kinerja yang dilakukan manajemen dalam mengelola 
kekayaan perusahaan yang ditunjukkan dengan laba yang dihasilkan (Novia Bani Nugraha, 2015). Profitabilitas dalam penelitian ini diukur dengan skala rasio, dengan rumus sebagai berikut:

$\mathrm{ROA}=\frac{\text { Laba bersih sebelum pajak }}{\text { Total aset }} \times 100 \%$

\section{Likuiditas}

Likuiditas didefinisikan sebagai kepemilikan sumber dana yang memadai untuk memenuhi kebutuhan dan kewajiban yang akan jatuh tempo serta kemampuan untuk membeli dan menjual asset dengan cepat (Adisamartha dan Noviari, 2015). Perusahaan dengan rasio likuiditas yang tinggi menunjukkan kemampuan perusahaan untuk memenuhi kewajiban jangka pendeknya, yang menandakan perusahaan dalam kondisi keuangan yang sehat serta dengan mudah menjual aset yang dimilikinya jika diperlukan (Suyanto, 2012). Likuiditas dalam penelitian ini diukur dengan skala rasio, dengan rumus sebagai berikut:

$$
\text { Current Ratio }=\frac{\text { Aset Lancar }}{\text { Kewajiban Lancar }} \times 100 \%
$$

\section{Leverage}

Leverage merupakan jumlah utang yang dimiliki perusahaan untuk pembiayaan dan dapat mengukur besarnya aktiva yang dibiayai utang. Perusahaan dengan leverage yang tinggi mengindikasikan perusahaan tersebut bergantung pada pinjaman luar atau utang, sedangkan perusahaan dengan leverage rendah dapat membiayai asetnya dengan modal sendiri.

Menurut Lanis dan Richardson (Novia Bani Nugraha, 2015), leverage dapat dihitung dengan skala rasio, dengan rumus sebagai berikut:

$$
\mathrm{LEV}=\frac{\text { Hutang Jangka Panjang }}{\text { Total Aset }} \times 100 \%
$$

\section{Intensitas Aset Tetap}

Intensitas Aset Tetap menunjukkan proporsi aset tetap di dalam perusahaan dibandingkan dengan total aset yang dimiliki. Intensitas Aset Tetap diperoleh dengan membandingkan total aset tetap dan total asset (Darmadi, 2013). Intensitas aset tetap dalam penelitian ini di ukur dengan skala rasio, dengan rumus sebagai berikut:

$$
\text { Intensitas Aset Tetap }=\frac{\text { Total Aset } \text { Tetap }}{\text { Total Aset }} \times 100 \%
$$

\section{Variabel Dependen}

Variabel dalam penelitian ini adalah agresivitas pajak. Agresivitas Pajak merupakan suatu tindakan yang dilakukan oleh perusahaan untuk mengurangi pendapatan kena pajak melalui perencanaan pajak (tax planning) baik secara legal yang dilakukan dengan penghindaran pajak (tax avoidance) maupun illegal yang dilakukan dengan penggelapan pajak (tax evasion) disebut dengan agresivitas pajak. Walau tidak semua tindakan yang dilakukan melanggar peraturan, namun semakin banyak celah yang digunakan perusahaan maka perusahaan tersebut dianggap semakin agresif (Mary Margaret Frank, Luann J Lynch, 2009).

Dalam penelitian ini variabel dependen yaitu agresivitas pajak perusahaan diukur dengan Effective Tax Rates (ETR) yang mengadopsi pengukuran yang dilakukan oleh Nugraha dan Meiranto menggunakan skala rasio (Novia Bani Nugraha, 2015), dengan rumus sebagai berikut:

$$
\mathrm{ETR}=\frac{\text { Beban Pajak Penghasilan }}{\text { Laba Bersih Sebelum Pajak }} \times 100 \%
$$

\section{HASIL}

Penelitian ini menggunakan populasi perusahaan pertambangan yang terdaftar di Bursa Efek Indonesia (BEI) pada periode tahun 2012-2016. Perolehan data yang digunakan melalui website www.idx.co.id. Perusahaan pertambangan tersebut telah terdaftar di Bursa Efek Indonesia sebelum 1 Januari 2012 dan selama periode penelitian tersebut tidak keluar dari Bursa Efek Indonesia atau mengalami delisting. Fokus penelitian ini adalah ingin memahami pengaruh profitabilitas, likuiditas, leverage dan intensitas asset tetap terhadap agresivitas pajak.

Pemilihan perusahaan-perusahaan publik yang termasuk kategori perusahaan sektor pertambangan ini didasarkan pada pertimbangan karena masih terbatasnya penelitian dengan populasi pada perusahaan sektor pertambangan, kebanyakan penelitian sebelumnya mengenai agresivitas pajak masih terkonsentrasi pada perusahaan sektor manufaktur. 
Berdasarkan kriteria yang telah ditetapkan dengan menggunakan metode purposive sampling, maka jumlah perusahaan yang berhasil diperoleh dalam penelitian ini sebanyak 12 perusahaan dengan total observasi 60 laporan keuangan perusahaan. Berikut nama-nama perusahaan yang menjadi sampel dalam penelitian ini.

Tabel 1. Daftar perusahaan pertambangan yang menjadi sampel

\begin{tabular}{|c|c|c|}
\hline No. & Kode Efek & Nama Emiten \\
\hline 1 & ANTM & PT. Antam Tbk. \\
\hline 2 & CITA & $\begin{array}{l}\text { PT. Cita Mineral } \\
\text { Investindo Tbk. }\end{array}$ \\
\hline 3 & СТTH & PT. Citatah Tbk. \\
\hline 4 & DKFT & $\begin{array}{l}\text { PT. Central Omega } \\
\text { Resources Tbk. }\end{array}$ \\
\hline 5 & ARTI & $\begin{array}{l}\text { PT. Ratu Prabu Energi } \\
\text { Tbk. }\end{array}$ \\
\hline 6 & MITI & $\begin{array}{l}\text { PT. Mitra Investindo } \\
\text { Tbk. }\end{array}$ \\
\hline 7 & SMMT & $\begin{array}{l}\text { PT. Golden Eagle Energy } \\
\text { Tbk. }\end{array}$ \\
\hline 8 & RUIS & $\begin{array}{l}\text { PT. Radiant } \\
\text { Intrinsco Tbk. }\end{array}$ \\
\hline 9 & ELSA & PT. Elnusa Tbk. \\
\hline 10 & PTBA & PT. Bukit Asam Tbk. \\
\hline 11 & PKPK & $\begin{array}{l}\text { PT. Perdana } \\
\text { Perkasa Tbk. }\end{array}$ \\
\hline 12 & TINS & PT. Timah (persero) Tbk. \\
\hline
\end{tabular}

\section{Teknik Analisis Data}

Statistik Deskriptif

Variabel penelitian yang digunakan dalam penelitian ini meliputi profitabilitas, likuiditas, leverage dan intensitas asset tetap sebagai variabel independen, agresivitas pajak sebagai variabel dependen. Hasil uji statistik deskriptif untuk variabel independen dan variabel dependen dapat dilihat pada tabel 2.

Berdasarkan tabel 2, hasil analisis dengan menggunakan statistik deskriptif terhadap agresivitas pajak, dari total pengamatan sebanyak 60 diperoleh nilai rata-rata (mean) 0.140781, standar deviasi 0.266469 , nilai maksimum sebesar 1 dan nilai minimum sebesar 0.002443 . Angka tersebut menunjukkan bahwa perusahaan melakukan agresivitas pajak sebesar $14 \%$. Hasil analisis profitabilitas menunjukkan nilai minimum sebesar 0.760201, nilai maksimum sebesar 8.844368, dengan rata-rata (mean) sebesar 2.886972 dan nilai standard deviasi sebesar 1.543602. Hasil analisis likuiditas menunjukkan nilai minimum sebesar 0,001060, nilai maksimum sebesar 0.066201 , dengan ratarata (mean) sebesar 0.008303, dan standard deviasi sebesar 0.009593. Hasil analisis leverage menunjukkan nilai minimum sebesar 0.718700 , nilai maksimum sebesar 6.282730 , dengan ratarata (mean) sebesar 3.438548 dan nilai standard deviasi sebesar 1.444469. Hasil analisis intensitas

Sumber: Bursa Efek Indonesia, 2017

Tabel 2. Hasil uji stastik deskriptif

\begin{tabular}{lllccc}
\hline & Agresiv_pjk & Profitabilitas & Likuiditas & Leverage & Aset_tetap \\
\hline Mean & 0.140781 & 2.886972 & 0.008303 & 3.438548 & 7.281743 \\
Median & 0.038146 & 2.525803 & 0.006076 & 3.518548 & 7.045944 \\
Maximum & 1.000000 & 8.844368 & 0.066201 & 6.282730 & 21.50533 \\
Minimum & 0.002443 & 0.760201 & 0.001060 & 0.718700 & 3.330889 \\
Std. Dev. & 0.266469 & 1.543602 & 0.009593 & 1.444469 & 2.304634 \\
Skewness & 2.525481 & 1.136502 & 4.364287 & -0.250961 & 3.791131 \\
Kurtosis & 8.006051 & 5.143204 & 24.69252 & 2.204795 & 25.46823 \\
Jarque-Bera & 126.4319 & 24.39969 & 1366.884 & 2.210692 & 1405.781 \\
Probability & 0.000000 & 0.000005 & 0.000000 & 0.331096 & 0.000000 \\
Sum & 8.446855 & 173.2183 & 0.498158 & 206.3129 & 436.9046 \\
Sum Sq. & 4.189329 & 140.5798 & 0.005430 & 123.1030 & 313.3689 \\
Dev. & & & & & 60 \\
Observations & 60 & 60 & 60 & 60 & 60 \\
\hline
\end{tabular}

Sumber: data diolah (Eviews 8) 
asset tetap menunjukkan nilai minimum sebesar 3.330889, nilai maksimum sebesar 21.50533, dengan rata-rata (mean) sebesar 7.281743 dan nilai standard deviasi sebesar 2.304634 .

Variabel profitabilitas, leverage dan intensitas asset tetap memiliki nilai rata-rata lebih besar dari nilai standard deviasi. Hal ini menunjukkan bahwa kualitas data dari variabel tersebut baik karena nilai rata-rata yang lebih besar dari nilai standar deviasinya, mengidentifikasikan bahwa standar error dari variabel tersebut kecil. Sedangkan variabel likuiditas dan agresivitas pajak memiliki nilai rata-rata yang lebih kecil dari nilai standar deviasi sehingga dapat diidentifikasi bahwa standar error dari variabel tersebut besar.

\section{Analisis regresi data panel}

\section{Pooled Least Square (Common Effect)}

Commom Effect Merupakan pendekatan model data panel yang paling sederhana karena hanya mengkombinasikan data time series dan cross section. Pada model ini tidak diperhatikan dimensi waktu maupun individu, sehingga diasumsikan bahwa perilaku data perusahaan sama dalam berbagai kurun waktu.

Berdasarkan tabel 3 model regresi linier berganda untuk common effect model sebagai berikut:

$\mathrm{Y}=-0.258+0.010$ profitabilitas +7.803 likuiditas +0.056 leverage +0.016 aset tetap.

\section{Fixed Effect Model (FEM)}

Teknik model fixed effect adalah teknik mengestimasi data panel dengan menggunakan variabel dummy untuk menangkap adanya perbedaan intersep. Pengertian fixed effect ini didasarkan adanya perbedaan intersep antara perusahaan namun intersepnya sama antar waktu (time in varian). Di samping itu, model ini juga mengasumsikan bahwa koefisien regresi (slope) tetap antar perusahaan dan antar waktu.

Tabel 3. Common effect model (CEM)

\begin{tabular}{lllll}
\hline \multicolumn{1}{c}{ Variable } & \multicolumn{1}{c}{ Coefficient } & \multicolumn{1}{c}{ Std. Error } & \multicolumn{1}{c}{ t-Statistic } & \multicolumn{1}{c}{ Prob. } \\
\hline C & -0.257289 & 0.166369 & -1.546492 & 0.1277 \\
PROFITABILITAS & 0.010079 & 0.022788 & 0.442302 & 0.6600 \\
LIKUIDITAS & 7.802402 & 3.497977 & 2.230547 & 0.0298 \\
LEVERAGE & 0.055177 & 0.024689 & 2.234905 & 0.0295 \\
ASET_TETAP & 0.015719 & 0.015320 & 1.026049 & 0.3094 \\
\hline R-squared & 0.165305 & Mean dependent var & 0.140781 \\
Adjusted R-squared & 0.104600 & S.D. dependent var & 0.266469 \\
S.E. of regression & 0.252148 & Akaike info criterion & 0.162051 \\
Sum squared resid & 3.496812 & Schwarz criterion & 0.336580 \\
Log likelihood & 0.138473 & Hannan-Quinn criter. & 0.230319 \\
F-statistic & 2.723082 & Durbin-Watson stat & 0.769881 \\
Prob(F-statistic) & 0.038547 & & \\
\hline
\end{tabular}

Sumber: data diolah (Eviews 8) 
JURNAL MADANI: Ilmu Pengetahuan, Teknologi, dan Humaniora, Vol. 4, No. 2, September 2021: 109 - 125

Tabel 4. Fixed effect model (FEM)

\begin{tabular}{lllll}
\hline \multicolumn{1}{c}{ Variable } & \multicolumn{1}{c}{ Coefficient } & \multicolumn{1}{c}{ Std. Error } & \multicolumn{1}{c}{ t-Statistic } & \multicolumn{1}{c}{ Prob. } \\
\hline C & -0.307860 & 0.129931 & -2.369408 & 0.0223 \\
PROFITABILITAS & 0.024864 & 0.020582 & 1.208068 & 0.2335 \\
LIKUIDITAS & 4.039012 & 2.652950 & 1.522461 & 0.1350 \\
LEVERAGE & 0.103605 & 0.023681 & 4.375049 & 0.0001 \\
ASET_TETAP & -0.001775 & 0.010761 & -0.164968 & 0.8697 \\
\hline \multicolumn{5}{c}{ Effects Specification } \\
\hline Cross-section fixed (dummy variables) & \multicolumn{5}{l}{} \\
\hline R-squared & 0.716145 & Mean dependent var & 0.140781 \\
Adjusted R-squared & 0.619377 & S.D. dependent var & 0.266469 \\
S.E. of regression & 0.164397 & Akaike info criterion & -0.549886 \\
Sum squared resid & 1.189161 & Schwarz criterion & 0.008605 \\
Log likelihood & 32.49659 & Hannan-Quinn criter. & -0.331430 \\
F-statistic & 7.400593 & Durbin-Watson stat & 1.750302 \\
Prob(F-statistic) & 0.000000 & & \\
\hline
\end{tabular}

Sumber: data diolah (Eviews 8)

Berdasarkan tabel 4 model regresi linier berganda untuk common effect model sebagai berikut: $\mathrm{Y}=-0.308+0.025$ profitabilitas +4.039 likuiditas +0.104 leverage -0.002 aset tetap.

\section{Random Effect Model (REM)}

Random effect model adalah model estimasi regresi panel dengan asumsi koefisien slope kontan dan intersep berbeda antara individu dan antar waktu (random effect). Dimasukannya variabel dummy di dalam fixed effect model bertujuan untuk mewakili ketidaktahuan tentang model yang sebenarnya. Namun, ini juga membawa konsekwensi berkurangnya derajat kebebasan (degree of freedom) yang pada akhirnya mengurangi efisiensi parameter. Masalah ini bisa diatasi dengan menggunakan variabel gangguan (error terms) yang dikenal dengan metode random effect. Model ini akan mengetimasi data panel di mana variabel gangguan mungkin saling berhubungan antar waktu dan antar individu.

Model yang tepat digunakan untuk mengestimasi random effect adalah generalized least square (GLS) sebagai estimatornya, karena dapat meningkatkan efisiensi dari least square.

Berdasarkan tabel 5 model regresi linier berganda untuk Random effect model sebagai berikut: $Y=-0.276+0.019$ profitabilitas +4.997 likuiditas
+0.090 leverage +0.002 aset tetap.

\section{Pemilihan Model Estimasi \\ Uji F Restricted (Chow Test)}

Berdasarkan tabel 6, menunjukkan bahwa nilai probabilitas Cross Section Chi-Square sebesar 0.0000 $<0.05$ maka dapat disimpulkan bahwa model yang diterima adalah fixed Effect Model (FEM).

\section{Uji Hausman}

Tahap kedua yang akan dilakukan yaitu uji Hausman, hasil pengujiannya dapat dilihat di tabel 7 .

Berdasarkan tabel 7, menunjukkan bahwa nilai probabilitas pada nilai Chi-Square sebesar 0.2102, nilai tersebut lebih besar dari 0,05 sehingga dapat disimpulkan bahwa menurut uji Hausman, model mengikuti Random Effect Model (REM).

\section{Uji Lagrange Multiplier (LM)}

Tahap ketiga yang akan dilakukan yaitu uji Langrange Multiplier, hasil pengujiannya dapat dilihat di tabel 8 .

Berdasarkan tabel 8, menunjukkan bahwa nilai probabilitas Breusch-Pagan sebesar 0.0000, nilai tersebut lebih kecil dari 0,05 sehingga dapat disimpulkan bahwa model mengikuti Random Effect Model (REM). Berikut kesimpulan pemilihan model regresi data panel. 
Tabel 5. Random effect model

\begin{tabular}{|c|c|c|c|c|}
\hline Variable & Coefficient & Std. Error & t-Statistic & Prob. \\
\hline $\bar{C}$ & -0.275997 & 0.136140 & -2.027304 & 0.0475 \\
\hline PROFITABILITAS & 0.019723 & 0.019317 & 1.021015 & 0.3117 \\
\hline LIKUIDITAS & 4.996870 & 2.573813 & 1.941427 & 0.0573 \\
\hline LEVERAGE & 0.090295 & 0.021839 & 4.134503 & 0.0001 \\
\hline ASET_TETAP & 0.001080 & 0.010616 & 0.101780 & 0.9193 \\
\hline \multicolumn{5}{|c|}{ Effects Specification } \\
\hline & & & S.D. & Rho \\
\hline Cross-section random & & & 0.187814 & 0.5662 \\
\hline Idiosyncratic random & & & 0.164397 & 0.4338 \\
\hline \multicolumn{5}{|c|}{ Weighted Statistics } \\
\hline R-squared & 0.283315 & \multicolumn{2}{|c|}{ Mean dependent var } & 0.051318 \\
\hline Adjusted R-squared & 0.231193 & \multicolumn{2}{|c|}{ S.D. dependent var } & 0.190629 \\
\hline S.E. of regression & 0.167147 & \multicolumn{2}{|c|}{ Sum squared resid } & 1.536594 \\
\hline F-statistic & 5.435559 & \multicolumn{2}{|c|}{ Durbin-Watson stat } & 1.250391 \\
\hline Prob(F-statistic) & 0.000924 & & & \\
\hline \multicolumn{5}{|c|}{ Unweighted Statistics } \\
\hline R-squared & 0.110619 & \multicolumn{2}{|c|}{ Mean dependent var } & 0.140781 \\
\hline Sum squared resid & 3.725910 & \multicolumn{2}{|c|}{ Durbin-Watson stat } & 0.672461 \\
\hline
\end{tabular}

Sumber: Data Diolah (Eviews 8)

Tabel 6. Hasil uji chow (chow test)

\begin{tabular}{|c|c|c|c|c|}
\hline \multicolumn{2}{|c|}{ Effects Test } & Statistic & d.f. & Prob. \\
\hline \multicolumn{2}{|l|}{ Cross-section F } & 7.762287 & $(11,44)$ & 0.0000 \\
\hline \multicolumn{2}{|c|}{ Cross-section Chi-square } & 64.716241 & 11 & 0.0000 \\
\hline Variable & Coefficient & Std. Error & t-Statistic & Prob. \\
\hline $\mathrm{C}$ & -0.257289 & 0.166369 & -1.546492 & 0.1277 \\
\hline PROFITABILITAS & 0.010079 & 0.022788 & 0.442302 & 0.6600 \\
\hline LIKUIDITAS & 7.802402 & 3.497977 & 2.230547 & 0.0298 \\
\hline LEVERAGE & 0.055177 & 0.024689 & 2.234905 & 0.0295 \\
\hline ASET_TETAP & 0.015719 & 0.015320 & 1.026049 & 0.3094 \\
\hline R-squared & 0.165305 & \multicolumn{2}{|c|}{ Mean dependent var } & 0.140781 \\
\hline Adjusted R-squared & 0.104600 & \multicolumn{2}{|c|}{ S.D. dependent var } & 0.266469 \\
\hline S.E. of regression & 0.252148 & \multicolumn{2}{|c|}{ Akaike info criterion } & 0.162051 \\
\hline Sum squared resid & 3.496812 & \multicolumn{2}{|c|}{ Schwarz criterion } & 0.336580 \\
\hline Log likelihood & 0.138473 & \multicolumn{2}{|c|}{ Hannan-Quinn criter. } & 0.230319 \\
\hline F-statistic & 2.723082 & \multicolumn{2}{|c|}{ Durbin-Watson stat } & 0.769881 \\
\hline Prob(F-statistic) & 0.038547 & & & \\
\hline
\end{tabular}

Sumber: data diolah (Eviews 8) 
Tabel 7. Uji hausman

\begin{tabular}{|c|c|c|c|c|}
\hline \multicolumn{2}{|c|}{ Test Summary } & Chi-Sq. Statistic & Chi-Sq. d.f. & Prob. \\
\hline \multicolumn{2}{|l|}{ Cross-section random } & 5.855332 & 4 & 0.2102 \\
\hline \multicolumn{5}{|c|}{ Cross-section random effects test comparisons: } \\
\hline Variable & Fixed & Random & Var(Diff.) & Prob. \\
\hline PROFITABILITAS & 0.024864 & 0.019723 & 0.000050 & 0.4693 \\
\hline LIKUIDITAS & 4.039012 & 4.996870 & 0.413628 & 0.1364 \\
\hline LEVERAGE & 0.103605 & 0.090295 & 0.000084 & 0.1460 \\
\hline ASET_TETAP & -0.001775 & 0.001080 & 0.000003 & 0.1053 \\
\hline Variable & Coefficient & Std. Error & t-Statistic & Prob. \\
\hline $\mathrm{C}$ & -0.307860 & 0.129931 & -2.369408 & 0.0223 \\
\hline PROFITABILITAS & 0.024864 & 0.020582 & 1.208068 & 0.2335 \\
\hline LIKUIDITAS & 4.039012 & 2.652950 & 1.522461 & 0.1350 \\
\hline LEVERAGE & 0.103605 & 0.023681 & 4.375049 & 0.0001 \\
\hline ASET_TETAP & -0.001775 & 0.010761 & -0.164968 & 0.8697 \\
\hline
\end{tabular}

Effects Specification

Cross-section fixed (dummy variables)

\begin{tabular}{llll}
\hline R-squared & 0.716145 & Mean dependent var & 0.140781 \\
Adjusted R-squared & 0.619377 & S.D. dependent var & 0.266469 \\
S.E. of regression & 0.164397 & Akaike info criterion & -0.549886 \\
Sum squared resid & 1.189161 & Schwarz criterion & 0.008605 \\
Log likelihood & 32.49659 & Hannan-Quinn criter. & -0.331430 \\
F-statistic & 7.400593 & Durbin-Watson stat & 1.750302 \\
Prob(F-statistic) & 0.000000 & & \\
\hline
\end{tabular}

Sumber: data diolah (Eviews 8)

Tabel 8. Hasil uji lagrange multiplier

\begin{tabular}{llll}
\hline \multicolumn{1}{c}{ Null (no rand. effect) Alternative } & Cross-section One-sided & Period One-sided & Both \\
\hline Breusch-Pagan & 30.52411 & 0.299647 & 30.82376 \\
& $(0.0000)$ & $(0.5841)$ & $(0.0000)$ \\
Honda & 5.524863 & -0.547401 & 3.519597 \\
& $(0.0000)$ & $(0.7079)$ & $(0.0002)$ \\
King-Wu & 5.524863 & -0.547401 & 2.384261 \\
& $(0.0000)$ & $(0.7079)$ & $(0.0086)$ \\
GHM & -- & -- & 30.52411 \\
& -- & -- & $(0.0000)$ \\
\hline
\end{tabular}

Sumber: data diolah (Eviews 8) 
Tabel 9. Kesimpulan pemilihan model

\begin{tabular}{llll}
\hline \multicolumn{1}{c}{ Jenis Uji } & Perbandingan Model & & Model Terpilih \\
\hline Uji Chow & CEM vs FEM & FEM & \\
Uji Hausman & REM vs FEM & REM \\
Uji Lagrange Multiplier & CEM vs REM & REM \\
\hline
\end{tabular}

Sumber: data diolah (Eviews 8)

\section{Uji Asumsi Klasik}

\section{Uji normalitas}

Ujinormalitas padapenelitianini menggunakan Eviews. Dalam Eviews, uji normalitas dapat dilakukan dengan uji Jerque-Bera (JB-test). Untuk mengambil keputusan, fokus pada JerqueBera dan Probability dengan membandingkan nilai JB dan nilai chi square tabel ( $x^{2}$ tabel).

Dalam Ghozali disebutkan, Uji JB-test adalah uji normalitas untuk sampel besar (asymptotic) (Ghozali, 2013). Untuk mendeteksi apakah residulnya berdistribusi normal atau tidak, dapat dilihat dari hasil perbandingan nilai JB dengan nilai chi square tabel kemudian dibandingkan kembali dengan kriteria berikut:

a. Jika nilai Jarque Bera $>x^{2}$ tabel, maka residualnya tidak berdistribusi normal.

b. Jika nilai Jarque Bera $<x^{2}$ tabel, maka residualnya berdistribusi normal.

Dari Gambar 1 terlihat bahwa Nilai jarque bera sebesar 60.44764 lebih kecil dari nilai chi square tabel sebesar 77,93 maka dapat disimpulkan bahwa data ini berdistribusi normal.

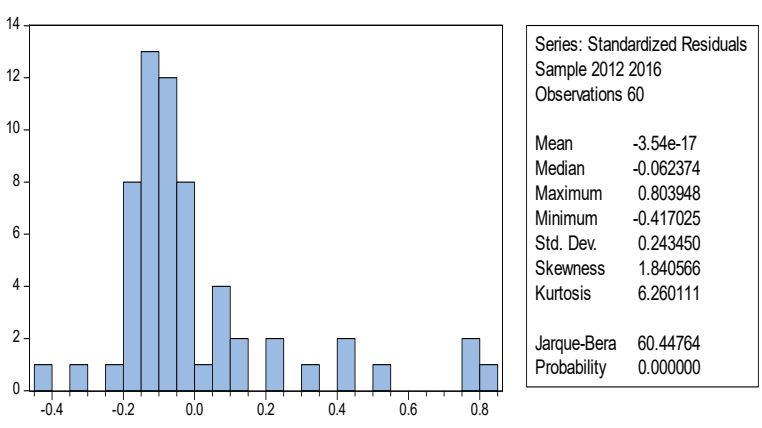

Gambar 1. Hasil uji normalitas data Sumber: data diolah (Eviews 8)

\section{Uji Multikolinieritas}

Berdasarkan Tabel 10, hasil perhitungan nilai Variance Inflation Factors (VIF) menunjukkan tidak ada satu pun variabel independen yang memiliki nilai VIF lebih dari 10. Jadi dapat disimpulkan bahwa tidak terjadi multikolinearitas antar variabel independen dalam model penelitian ini.

\section{Uji heterokedastisitas}

Berdasarkan Tabel 11, hasil perhitungan uji heterokedastitas menunjukkan bahwa nilai Obs*R-Squared mempunyai nilai prob. ChiSquare sebesar 0,07547, hal ini berarti bahwa tidak ada gejala heterokedastisitas yang terjadi.

Tabel 10. Hasil uji multikolinearitas

\begin{tabular}{llll}
\hline \multicolumn{1}{c}{ Variable } & Coefficient Variance & Uncentered VIF & Centered VIF \\
\hline C & 0.027679 & 26.12095 & NA \\
PROFITABILITAS & 0.000519 & 5.232663 & 1.148208 \\
LIKUIDITAS & 12.23584 & 1.840955 & 1.044965 \\
LEVERAGE & 0.000610 & 7.981410 & 1.180195 \\
ASET_TETAP & 0.000235 & 12.90142 & 1.156836 \\
\hline
\end{tabular}

Sumber: data diolah (Eviews 8) 
Tabel 11. Hasil uji heterokedastisitas

\begin{tabular}{|c|c|c|c|c|}
\hline \multicolumn{5}{|l|}{ Heteroskedasticity Test: White } \\
\hline F-statistic & & 0.650698 & Prob. F(14,45) & 0.8076 \\
\hline Obs*R-squared & & 10.10144 & Prob. Chi-Square(14) & 0.7547 \\
\hline Scaled explained SS & & 90.38775 & Prob. Chi-Square(14) & 0.0000 \\
\hline Variable & Coefficient & Std. Error & t-Statistic & Prob. \\
\hline $\mathrm{C}$ & -6509.260 & 35531.84 & -0.183195 & 0.8555 \\
\hline PROFITABILITAS^2 $^{\wedge}$ & -3.570535 & 16.22629 & -0.220046 & 0.8268 \\
\hline PROFITABILITAS*LIKUIDITAS & 4.777950 & 5.770951 & 0.827931 & 0.4121 \\
\hline PROFITABILITAS*LEVERAGE & -114.4223 & 68.75103 & -1.664300 & 0.1030 \\
\hline PROFITABILITAS*ASET_TETAP & -6.393416 & 24.24451 & -0.263706 & 0.7932 \\
\hline PROFITABILITAS & 503.4210 & 1803.331 & 0.279162 & 0.7814 \\
\hline LIKUIDITAS^2 & -0.136860 & 0.136409 & -1.003307 & 0.3211 \\
\hline LIKUIDITAS*LEVERAGE & -0.785352 & 2.848794 & -0.275679 & 0.7841 \\
\hline LIKUIDITAS*ASET_TETAP & 1.579816 & 2.750289 & 0.574418 & 0.5685 \\
\hline LIKUIDITAS & -18.07175 & 184.0834 & -0.098172 & 0.9222 \\
\hline LEVERAGE`2 $^{\wedge}$ & -19.16329 & 33.73241 & -0.568097 & 0.5728 \\
\hline LEVERAGE*ASET_TETAP & 6.896275 & 28.25544 & 0.244069 & 0.8083 \\
\hline LEVERAGE & 1222.040 & 1653.534 & 0.739048 & 0.4637 \\
\hline ASET_TETAP^2 & -0.600641 & 0.652580 & -0.920410 & 0.3623 \\
\hline ASET_TETAP & -98.78678 & 740.7482 & -0.133361 & 0.8945 \\
\hline R-squared & 0.168357 & Mean depen & dent var & 4170.387 \\
\hline Adjusted R-squared & -0.090376 & S.D. depend & ent var & 19408.53 \\
\hline S.E. of regression & 20266.60 & Akaike info & criterion & 22.88365 \\
\hline Sum squared resid & $1.85 \mathrm{E}+10$ & Schwarz cri & erion & 23.40724 \\
\hline Log likelihood & -671.5096 & Hannan-Qui & nn criter. & 23.08846 \\
\hline F-statistic & 0.650698 & Durbin-Wat & on stat & 2.041681 \\
\hline Prob(F-statistic) & 0.807595 & & & \\
\hline
\end{tabular}

Sumber: data diolah (Eviews 8) 
Tabel 12. Random effect model

\begin{tabular}{lllll}
\hline \multicolumn{1}{c}{ Variable } & \multicolumn{1}{c}{ Coefficient } & \multicolumn{1}{c}{ Std. Error } & t-Statistic & Prob. \\
\hline C & -0.275997 & 0.136140 & -2.027304 & 0.0475 \\
PROFITAB B LI - & 0.019723 & 0.019317 & 1.021015 & 0.3117 \\
TAS & & & & \\
LIKUIDITAS & 4.996870 & 2.573813 & 1.941427 & 0.0573 \\
LEVERAGE & 0.090295 & 0.021839 & 4.134503 & 0.0001 \\
ASET_TETAP & 0.001080 & 0.010616 & 0.101780 & 0.9193 \\
\hline
\end{tabular}

Effects Specification

\begin{tabular}{|c|c|c|c|}
\hline \multicolumn{2}{|c|}{ Crocesention rondom } & S.D & Rho \\
\hline \multicolumn{2}{|c|}{ Cross-section random } & 0.187814 & 0.5662 \\
\hline \multicolumn{2}{|c|}{ Idiosyncratic random } & 0.164397 & 0.4338 \\
\hline \multicolumn{4}{|c|}{ Weighted Statistics } \\
\hline R-squared & 0.283315 & Mean dependent var & 0.051318 \\
\hline $\begin{array}{l}\text { Adjusted R- } \\
\text { squared }\end{array}$ & 0.231193 & S.D. dependent var & 0.190629 \\
\hline S.E. of regression & 0.167147 & Sum squared resid & 1.536594 \\
\hline F-statistic & 5.435559 & Durbin-Watson stat & 1.250391 \\
\hline Prob(F-statistic) & 0.000924 & & \\
\hline \multicolumn{4}{|c|}{ Unweighted Statistics } \\
\hline R-squared & 0.110619 & Mean dependent var & 0.140781 \\
\hline Sum squared resid & 3.725910 & Durbin-Watson stat & 0.672461 \\
\hline
\end{tabular}

Sumber: data diolah (Eviews 8)

\section{Pengujian Hipotesis}

1. Uji Signifikansi Simultan (F)

Berdasarkan pada tabel output 12, diperoleh nilai Fhitung sebesar 5.44 dan Ftabel sebesar 2,54 Oleh karena itu Fhitung> Ftabel dapat disimpulkan bahwa koefisien regresi PROFITABILITAS, LIKUIDITAS, LEVERAGE, ASET_TETAP tidak sama dengan nol atau dengan kata lain H1 diterima dan menolak H0. Kesimpulan hasil outputnya adalah keempat variabel independen secara simultan berpengaruh signifikan terhadap Agresivitas Pajak.

2. Uji signifikansi parameter individual (uji t)

Hipotesis Pertama

Berdasarkan tabel 12 nilai signifikansi sebesar $0.3117>0.05$ dengan nilai thitung sebesar 1.021015 < ttabel sebesar 2.00404 berdasarkan hasil diatas maka $\mathrm{H} 1$ ditolak dan $\mathrm{H} 0$ diterima, yang berarti profitabilitas tidak berpengaruh signifikan terhadap agresivitas pajak secara parsial. Dengan demikian H1 tidak terbukti mendeteksi agresivitas pajak.

Hipotesis Ketiga

Berdasarkan tabel 12 nilai signifikansi sebesar $0.0001<0.05$ dengan nilai thitung sebesar 4.134503 > ttabel sebesar 2.00404 berdasarkan hasil diatas maka $\mathrm{H} 0$ ditolak dan $\mathrm{H} 1$ diterima, yang berarti leverage berpengaruh signifikan terhadap agresivitas pajak secara parsial. Dengan demikian $\mathrm{H} 3$ terbukti mendeteksi agresivitas pajak.

\section{Hipotesis Keempat}

Berdasarkan tabel 12 nilai signifikansi sebesar $0.9193>0.05$ dengan nilai thitung sebesar $0.101780<$ ttabel sebesar 2.00404 berdasarkan hasil diatas maka $\mathrm{H} 1$ ditolak dan $\mathrm{H} 0$ diterima, yang berarti intensitas aset tetap tidak berpengaruh signifikan terhadap agresivitas pajak secara parsial. Dengan demikian H4 tidak terbukti mendeteksi agresivitas pajak.

\section{Uji koefisien determinasi $\left(R^{2}\right)$}

Tampilan output pada tabel 12 menunjukan 
besarnya R-squared sebesar 0.284 , hal ini berarti 28,4\% variasi agresivitas pajak dapat dijelaskan oleh variasi dari lima variabel independen Profitabilitas, likuiditas, leverage dan intensitas asset tetap (ASET TETAP) sedangkan sisanya $71.6 \%$ dijelaskan oleh sebab-sebab lain di luar model dalam penelitian ini. yang rendah akan tidak taat pada pembayaran pajak guna mempertahankan aset perusahaan dari pada harus membayar pajak. Penelitian ini sejalan dengan penelitian fikriyah yang menunjukan profitabilitas tidak berpengaruh signifikan terhadap agresivitas pajak (Fikriyah, 2014).

Tabel 13. Hasil regresi panel random effect model

\begin{tabular}{|c|c|c|c|c|}
\hline Variable & Coefficient & Std. Error & t-Statistic & Prob. \\
\hline $\mathrm{C}$ & -0.275997 & 0.136140 & -2.027304 & 0.0475 \\
\hline PROFITABILITAS & 0.019723 & 0.019317 & 1.021015 & 0.3117 \\
\hline LIKUIDITAS & 4.996870 & 2.573813 & 1.941427 & 0.0573 \\
\hline LEVERAGE & 0.090295 & 0.021839 & 4.134503 & 0.0001 \\
\hline ASET_TETAP & 0.001080 & 0.010616 & 0.101780 & 0.9193 \\
\hline \multicolumn{5}{|c|}{ Effects Specification } \\
\hline & & & S.D. & Rho \\
\hline Cross-section random & & & 0.187814 & 0.5662 \\
\hline Idiosyncratic random & & & 0.164397 & 0.4338 \\
\hline \multicolumn{5}{|c|}{ Weighted Statistics } \\
\hline R-squared & 0.283315 & \multicolumn{2}{|c|}{ Mean dependent var } & 0.051318 \\
\hline Adjusted R-squared & 0.231193 & \multicolumn{2}{|c|}{ S.D. dependent var } & 0.190629 \\
\hline S.E. of regression & 0.167147 & \multicolumn{2}{|c|}{ Sum squared resid } & 1.536594 \\
\hline F-statistic & 5.435559 & \multicolumn{2}{|c|}{ Durbin-Watson stat } & 1.250391 \\
\hline Prob(F-statistic) & 0.000924 & & & \\
\hline \multicolumn{5}{|c|}{ Unweighted Statistics } \\
\hline R-squared & 0.110619 & Mean depend & var & 0.140781 \\
\hline Sum squared resid & 3.725910 & Durbin-Wats & & 0.672461 \\
\hline
\end{tabular}

Sumber: data diolah (Eviews 8)

\section{Pembahasan}

\section{Pengaruh Profitabilitas terhadap Agresivitas Pajak}

Berdasarkan sebaran tabel yang dijelaskan di atas nilai signifikansi sebesar $0.3117>0.05$ dengan nilai thitung sebesar $1.021015<$ ttabel sebesar 1.67303 maka H1 ditolak dan H0 diterima, yang berarti profitabilitas berpengaruh tidak signifikan terhadap agresivitas pajak secara parsial. Dengan demikian H1 tidak terbukti mendeteksi agresivitas pajak.

Hal ini menyatakan bahwa profitabilitas sebuah perusahaan merupakan satu indikator yang mencerminkan kesehatan keuangan suatu perusahaan.

Dan bisa diketahui bahwa perusahaan yang mempunyai tingkat profitabilitas yang tinggi akan selalu mentaati pembayaran pajak. Sedangkan untuk perusahaan yang mempunyai tingkat profitabilitas

\section{Pengaruh Likuiditas terhadap Agresivitas Pajak}

Berdasarkan tabel di atas nilai signifikansi sebesar $0.0573>0.05$ dengan nilai thitung sebesar $1.941427>$ ttabel sebesar 1.67303 maka H1 ditolak dan H0 diterima, yang berarti likuiditas berpengaruh tidak signifikan terhadap agresivitas pajak secara parsial. Dengan demikian H2 tidak terbukti mendeteksi agresivitas pajak. Likuiditas yang terlalu menggambarkan tingginya uang tunai yang mengganggur sehinggga dianggap kurang produktif, akan tetapi jika likuiditas terlalu rendah maka akan mengurangi tingkat kepercayaan kreditur terhadap perusahaan dan bisa berakibat pinjaman modal oleh para kreditur menurun. Maka ada kemungkinan perusahaan menjaga tingkat likuiditas pada tingkat tertentu 
sehingga tidak ditemukannya pengaruh likuiditas pada agresivitas pajak.

Penelitian ini sejalan dengan penelitian Desi Nawang Gemilang yang menunjukan likuiditas tidak berpengaruh signifikan terhadap agresivitas pajak (Gemilang, 2017). Meski demikian, hasil penelitian ini tidak sejalan dengan penelitian yang dilakukan oleh Bagus dan Noviari yang menyatakan bahwa likuiditas berpengaruh positif dan signifikan pada tingkat agresivitas pajak (Ida Bagus Putu Fajar Adisamartha, 2015).

\section{Pengaruh Leverage terhadap Agresivitas Pajak}

Berdasarkan tabel di atas nilai signifikansi sebesar $0.0001<0.05$ dengan nilai thitung sebesar $4.134503>$ ttabel sebesar 1.67303 maka H0 ditolak dan $\mathrm{H} 1$ diterima, yang berarti leverage berpengaruh signifikan terhadap agresivitas pajak secara parsial. Dengan demikian H3 terbukti mendeteksi agresivitas pajak. Hal ini menyatakan bahwa besar kecil nya leverage pada perusahaan dapat mempengaruhi besar kecilnya pajak yang dibayarkan perusahaan. Hal ini dikarenakan biaya bunga dari utang dapat dikurangkan dalam menghitung pajak sehingga beban pajak menjadi lebih kecil. Hasil penelitian ini sejalan dengan penelitian yang dilakukan oleh Kurniasih dan Sari (Kurniasih \& Ratna Sari, 2013) serta Sabrina dan Supriyanto (Suyanto \& Supramono, 2012) yang menyatakan bahwa leverage berpengaruh signifikan terhadap agresivitas pajak perusahaan.

Hasil penelitian ini tidak sejalan dengan penelitian Fikriyah (Fikriyah, 2014) yang menghasilkan bukti leverage tidak berpengaruh dan menunjukkan arah negatif, yang berarti bahwa semakin tinggi leverage maka agresivitas pajak pada perusahaan akan semakin rendah.

\section{Pengaruh Intensitas Aset Tetap terhadap Agresivitas Pajak}

Berdasarkan tabel di atas nilai signifikansi sebesar $0.9193>0.05$ dengan nilai thitung sebesar 0.101780 < ttabel sebesar 1.67303 maka H1 ditolak dan $\mathrm{H0}$ diterima, yang berarti intensitas aset tetap berpengaruh tidak signifikan terhadap agresivitas pajak secara parsial. Dengan demikian H4 tidak terbukti mendeteksi agresivitas pajak.
Perusahaan dengan tingkat aset tetap tinggi tidak mampu memanfaatkan beban depresiasi untuk mengurangi laba bersih. Aset tetap tersebut mampu meningkatkan operasional perusahaan dan meningkatkan laba bersih lebih tinggi dibandingkan beban depresiasi yang dibebankan pada aset tetap. Hasil penelitian ini sejalan dengan penelitian yang dilakukan oleh Ida Bagus Putu Fajar dan Naniek Noviari yang menyatakan intensitas aset tetap tidak berpengaruh signifikan terhadap agresivitas pajak (Ida Bagus Putu Fajar Adisamartha, 2015).

Pengaruh profitabilitas, likuiditas, leverage dan intenitas aset tetap terhadap agresivitas pajak

Berdasarkan pada tabel di atas, diperoleh nilai Fhitung sebesar 5.44 dan Ftabel sebesar 2,54 Oleh karena itu Fhitung> Ftabel dapat disimpulkan bahwa koefisien regresi PROFITABILITAS, LIKUIDITAS, LEVERAGE, ASET_TETAP tidak sama dengan nol atau dengan kata lain H1 diterima dan menolak H0. Kesimpulan hasil outputnya adalah keempat variabel independen secara simultan berpengaruh signifikan terhadap Agresivitas Pajak.

\section{SIMPULAN}

Mendapatkan bukti empiris atas pengaruh dari profitabilitas, likuiditas, leverage dan intensitas aset tetap pada perusahaan pertambangan periode 2012-2016 merupakan tujuan penelitian ini. Maka dapat disimpulkan bahwa Profitabilitas berpengaruh tidak signifikan terhadap agresivitas pajak dengan demikian $\mathrm{H} 1$ tidak terbukti mendeteksi agresivitas pajak. Penelitian ini sejalan dengan penelitian Fikriyah (2013) yang menunjukkan profitabilitas tidak berpengaruh signifikan terhadap agresivitas pajak.

Likuiditas berpengaruh tidak signifikan terhadap agresivitas pajak dengan demikian H2 tidak terbukti mendeteksi agresivitas pajak. Penelitian ini sejalan dengan penelitian Desi Nawang Gemilang (2017) yang menunjukan likuiditas tidak berpengaruh signifikan terhadap agresivitas pajak.

Leverage berpengaruh signifikan terhadap agresivitas pajak dengan demikian $\mathrm{H} 3$ terbukti 
mendeteksi agresivitas pajak. Penelitian ini sejalan dengan penelitian Kurniasih dan Sari (2013) serta Sabrina dan Supriyanto (2013) yang menyatakan bahwa leverage berpengaruh signifikan terhadap agresivitas pajak perusahaan.

Intensitas aset tetap dengan proksi ASET TETAP berpengaruh tidak signifikan terhadap agresivitas pajak dengan demikian $\mathrm{H} 4$ tidak terbukti mendeteksi agresivitas pajak. Penelitian ini juga sejalan dengan penelitian Ida Bagus Putu Fajar dan Naniek Noviari (2015) yang menyatakan intensitas aset tetap tidak berpengaruh signifikan terhadap agresivitas pajak. Profitabilitas, Likuiditas, Leverage dan intensitas Aset Tetap bersama-sama berpengaruh signifikan terhadap agresivitas pajak dengan demikian H5 terbukti mendeteksi agresivitas pajak.

\section{PENGHARGAAN}

Keberhasilan penulis dalam menyelesaikan penelitian ini tidak terlepas dari bimbingan, arahan, doa, dan dukungan dari berbagai pihak. Untuk itu penulis mengucapkan terima kasih yang sebesar-besarnya kepada pihak-pihak yang terlibat.

\section{DAFTAR PUSTAKA}

Ardyansah, D. (2014). Pengaruh Size, Leverage, Profitability, Capital Intensity Ratio Dan Komisaris Independen Terhadap Effective Tax Rate (Etr). Diponegoro Journal of Accounting, 3(2), 371-379.

Chen, S., Chen, X., Shevlin, T., Chen, S., Chen, X., \& Shevlin, T. (2010). Institutional Knowledge at Singapore Management University Are Family Firms more Tax Aggressive than Non-family Firms? Are family firms more tax aggressive than non-family firms? * University of Texas at Austin University of Wisconsin-Madison. Research Collection School of Accountancy, 91(1), 41-61.

Fikriyah, F. (2014). Analisis pengaruh likuiditas, leverage, profitabilitas dan karakteristik kepemilikan terhadap agresivitas pajak perusahaan: Studi pada perusahaan sektor pertambangan yang terdaftar di BEI pada tahun 2010-2012. Maulana Malik Ibrahim.
Gemilang, D. N. (2017). Pengaruh Likuiditas, Leverage, Profitabilitas, Ukuran Perusahaan Dan Capital Intensity Terhadap Agresivitas Pajak Perusahaan (Studi Empiris Pada Perusahaan Property Dan Real Estate Yang Terdaftar Di BEI Pada Tahun 2013-2015). Institut Agama Islam Negeri Surakarta.

Ghozali, I. (2013). Ap-likasi Analisis Multivariate dengan Program SPSS. Universitas Diponegoro.

Houston, E. F. B. J. F. (2001). Manajemen Keuangan. Erlangga.

Ida Bagus Putu Fajar Adisamartha, N. N. (2015). Pengaruh Likuiditas, Leverage, Intensitas Persediaan Dan Intensitas Aset Tetap Pada Tingkat Agresivitas Wajib Pajak Badan. E-Jurnal Akuntansi, 13(3), 973-1000.

Kurniasih, T., \& Ratna Sari, M. (2013). Pengaruh Return on Assets, Leverage, Corporate Governance, Ukuran Perusahaan Dan Kompensasi Rugi Fiskal Pada Tax Avoidance. Buletin Studi Ekonomi, 18(1), 58-66.

Mary Margaret Frank, Luann J Lynch, S. O. R. (2009). Tax Reporting Aggressiveness and Its Relation to Aggressive Financial Reporting. The Accounting Review, 84, 467-496.

Novia Bani Nugraha, W. M. (2015). Pengaruh Corporate Social Responbility, Ukuran Perusahaan, Profitabilitas, Leverage dan Capital Intensity Terhadap Agresivitas Pajak. Diponegoro Journal of Accounting, 4(4), 1-14. http://ejournal-s1.undip.ac.id/index. php/accounting.

Prakoso, K. B. (2014). Pengaruh Profitabilitas, Kepemilikan Keluarga dan Corporate Governance Terhadap Penghindaraan Pajak Di Indonesia. Simposium Nasional Akuntansi 17.

Putri, L. T. Y. (2014). 2 Pengaruh likuiditas, manajemen laba dan corporate governance terhadap agresivitas pajak perusahaan. Pengaruh Likuiditas, Manajemen Laba Dan Corporate Governance Terhadap Agresivitas Pajak Perusahaan, 1-25.

Rego, S. O. (2003). Tax-Avoidance Activities of U.S. Multinational Corporations. Contemporary Accounting Research, 20(4), 
805-833. https://doi.org/10.1506/VANNB7UB-GMFA-9E6W

Scott, W. R. . (2009). Financial Accounting Theory. Pearson Prentice Hall.

Sugiyono. (2019). Metode Penelitian Kuantitatif Kualitatif dan R\&D. Alfabeta.

Suprapto, Y. (2019). Jambi Masih Membara, Perkumpulan Hijau: Evaluasi Izin di Lahan Gambut. Mongabay.Co.Id. https://www. mongabay.co.id/2019/09/13/jambi-masihmembara-perkumpulan-hijau-evaluasi-izindi-lahan-gambut/.

Suyanto, K. D., \& Supramono. (2012). Likuiditas, Leverage, Komisaris Independen, Dan Manajemen Laba Terhadap Agresivitas Pajak Perusahaan. Jurnal Keuangan Dan Perbankan, 16(2), 167-177. http://jurkubank.wordpress. com. 